\title{
The Classic Years of European Marxism, 1887-1936
}

\author{
Gerd-Rainer Horn
}

Stanley Pierson, Marxist Intellectuals and the Working-Class Mentality in Germany, 1887-1912 (Cambridge: Harvard University Press 1993).

Donna Harsch, German Social Democracy and the Rise of Nazism (Chapel Hill: University of North Carolina Press 1993).

Stanley G. Payne, Spain's First Democracy: The Second Republic, 1931-1936 (Madison: University of Wisconsin Press 1993).

In the 1950s a host of western intellectuals eagerly announced The End of Ideology, a prediction in part based on a precipitous decline in the influence of Marxism in several advanced industrialized states. The world-wide instance and impact of 1968 quickly relegated such triumphant pronoucements to the (temporary) rubbish heap of history. The $1970 \mathrm{~s}$, in particular, saw a substantive and unexpected revival of the Marxist tradition in many corners of the globe. Yet the demise of the Portuguese Revolution and the slow extinction of Italy's 'creeping May' did much to dampen European Marxist spirits, leading many erstwhile Marxists to declare, in the course of the 1980s, their Adieux au prolétariat. Finally, the recent implosion of most examples of 'actually existing socialism' seems to have definitively moved back the clock to the $1950 \mathrm{~s}$ again, with discussions of The End of History dominating the intellectuals' terrain.

Was global 1968 the last gasp of a dying era rather than a portent of greater things to come? Regardless of the answer, a sober assessment of 1968 shows that the actual events associated with that year bear only limited correspondence with the predictions of the Marxist school. France and Czechoslovakia were, in a sense, the two exceptions which squarely fit the Marxist emphasis on the role of the proletariat in the emancipatory process. Most everyplace else saw non-proletarian activists in the forefront of events. And even France and Czechoslovakia were less than brilliant cases of the forward march of history. The brutal repression of the Prague Spring by a coalition of nominally Marxist forces and the sudden acquiescence of the 
French working class, when offered a hefty wage increase, served to cloud the certainties of orthodox Marxists. Only the soon ascending Italian 'creeping May' and the later flickers of the 'revolution of the carnations' helped to stave off graver doubts for a while.

The last major wave of working class activism prior to the late 1960s and the 1970s, the tremendous wave of World War II resistance movements in southern Europe, had also been a less-than-classic case of proletarian selfemancipation via class struggle, similar to most instances of 1968 . While certainly in Italy, Greece, and Yugoslavia firmly rooted in the working class left, it can be argued that the social-emancipatory dimension of antifascist resistance owed much of its overwhelming domestic support to its close identification with, and its origins in, the issues and the aura of national liberation. The survival of strongholds of Marxist beliefs in much of southern Europe throughout the post-World War II decades, then, ironically owed much to yet another transnational social movement, the Resistance, which clearly did not correspond to the parameters of social action proclaimed by Marxist orthodoxy.

If 1968 and World War II resistance movements did not conform to Marxist predictions, was there ever a time when prototypical working class movements determined major aspects of a country's or a continent's social, political, and cultural landscape? Was there ever a time when Marxism appeared to coincide with actual events and processes?

The answer is yes. And this is where the three books under review fit in rather well, as they elucidate key aspects of the one time span which tended to confirm Marxist beliefs, the years 1887-1936. Arguably, these fifty years were, thus far, the only years in which the major social trends in European society tended to conform with orthodox Marxist tenets. These fifty years were the only ones in which nominally Marxist parties with a working class base were willingly or unwillingly engaged in economic and political class struggle activities thereby crucially determining the contours of their societies and the continent as a whole.

Admittedly, 1887 is a somewhat arbitrary starting date of this historical period. (The closing date, as we will see, is far more precise). Stanley Pierson chose it for his study in part because July 1887 saw the birth of the first journalistic venture of SPD intellectuals which gave rise to inner-party controversy. The relevance of the late 1880 s as the starting date of the "fifty years of Marxist hegemony" is underscored by the following observation. The closing years of Bismarck's Socialist Laws experienced the apparent irreversibility of the rise of German Marxism to prominence. And from this German 'home base,' Marxism set out in subsequent decades to conquer many organized European workers' worlds. 
Stanley Pierson's contribution is two-fold, focussing on two prominent real or potential contradictions in the theory and practice of German Marxism. First, Pierson points out three faces of Marxism that may not always peacefully coexist. The 'critical' face of Marxism grows out of the Marxist claim adequately to represent the main features and inherent contradictions of contemporary societies. The 'apologetic' face of Marxism pertains to Marxist identification with working class interests. The 'visionary' face of Marxism derives from Marxist advocacy of the necessity of radical social and political change in order to see working class interests win out over the constraints of contemporary society. Second, Pierson underscores the inherent contradiction in Marxist claims between a fervent belief in economic determinism and the simultaneous recognition of human agency as a key motor force of history.

Both insights are obviously not unique to Pierson. What makes his study somewhat unusual is Pierson's focus on the role of intellectuals in the evolution of Marxism in Germany. Pierson systematically addresses the role intellectuals played in the theory and practice of German social democracy, along the way casting interesting glances at many long-forgotten issues polarizing the early German Social Democratic Party (SPD). For intellectuals amongst the party's ranks, the situation around the turn of the century was already less than ideal, as the later observation by Hendrik de Man underscores, a citation serving as the opening lines to Pierson's work: "Few among the active Social Democratic intellectuals ever lose the depressing feeling that one is suffered as a guest in a foreign home, whose inhabitants have other habits."

It is one of Pierson's key conclusions that many, though by no means all, SPD intellectuals spent much of their productive time trying to grapple with the intricacies of these two contradictions. Thus it was only too natural for intellectuals to cast doubts on the validity of economic determinism, for a strict interpretation of that thesis would have relegated the position of party intellectuals to that of loyal workers amongst a multitude of party workers, with no special responsibilities. The opposite pole of this contradiction, a stress on voluntarism, the need to work at convincing a majority of people (workers) of the validity of Marxist forecasts, held much more promise and promised more fame to party intellectuals.

Karl Kautsky and Franz Mehring were only two of many SPD intellectuals who began their socialist career firmly convinced of the spontaneous generation of revolutionary working-class consciousness on the basis of workers' objective experiences but then soon altered their approach and adopted various forms of interventionist beliefs combined with elements of paternalism. Pierson highlights Rosa Luxemburg as a different example of a party intellectual, someone consistently proclaiming both economic determinism and working-class spontaneity as two sides of an asymmetrical coin. Yet Luxemburg was the exception proving the rule. Growing disbelief in the 
supposedly objectively determined march of history was a key factor behind the rise of revisionism. The revisionist Lily Braun utilized the assault on determinist certainties in other areas as a loophole from which to set out in pursuit of an equally iconoclastic union of feminism and Marxism. Some revisionists eventually even arrived at the conclusion that there was no need for any attempts to instill the 'proper' working-class consciousness, as they came to regard this much-proclaimed goal as a figment of the imagination, something that would come about neither automatically nor as a result of artificial stimulation by intellectuals. Meanwhile radical Marxists, like Anton Pannekoek, developed proto-Gramscian notions of bourgeois cultural hegemony in an attempt to ascertain why German workers had not yet achieved their true calling. And German syndicalists within the SPD broke with the determinist variant of Marxist orthodoxy by proclaiming the necessity to instill enthusiasm in the masses on the road to power.

On balance most party intellectuals, regardless of their factional allegiances, opted for an active role for Marxist intellectuals in the genesis of the desired class consciousness, despite frequent continued adherence to the tenets of economic determinism. It was therefore only symptomatic that the SPD party leadership in 1906 chose an utterly traditional format when establishing a party school in Berlin. Rejecting Otto Rühle's proposal to establish decentralized correspondence courses in which proletarian party members would be trained in reading, writing and rhetoric so that they could become an 'intellectual elite' themselves, the party opted for Heinrich Schulz's idea to create a central party school where 'talented young comrades' could be imbued with the spirit of orthodox Marxist theory.

Compared to his treatment of the contradictions between determinism and agency (mediated by intellectuals), Pierson's discussion of the interplay of the three faces of Marxism is less convincing. Perhaps his major conceptual lapse is the repeated unjustified equation of the defense of working-class interests, the 'apologetic' face of Marxism, with the defense of the party structure and infrastructure as such. While there is nothing wrong in pointing out this party-centered pragmatism throughout the early history of the SPD, it should have been identified as an analytically separate, perhaps a fourth, face of Marxism.

But this tendency towards the blurring of analytical distinctions is a more common problem of Pierson's study. Major portions of this work consist of a somewhat overly detailed recounting of many SPD debates with scant and incidental attention given to analytical conclusions. Moreover, given the focus on party intellectuals belonging to dissident factions of the right or left, the reader can easily lose sight of the fact that party intellectuals were aligned on all sides of the factional divides, including the silent majority of the frequently shifting party center. Furthermore, many leading spokespersons for 
any number of party tendencies, such as August Bebel and Eduard Bernstein, cannot be classified as intellectuals in any usual sense of that term. To Pierson's credit, he does on occasion remind the reader of this less-thanclearcut state of affairs, but he fails to draw the necessary conclusions. For, rather than being a problem affecting party intellectuals only or mostly, did not the contradiction between determinism and voluntarism affect all party activists alike?

Marxist Intellectuals and the Working-Class Mentality ends in 1912. German Social Democracy and the Rise of Nazism picks up the story sixteen years later. But the storyline and the actors within it are almost completely different. Within Europe as a whole the years 1912-1928 witnessed one world war; the demise of the Hohenzollern, Habsburg, and Romanov dynasties; a wave of working-class unrest (1917-1923); and several failed - and one successful - Soviet republics. Small wonder that in 1928 little would be as it had been in 1912, in Germany and elsewhere on the continent.

Yet the same contradictions that Pierson targets in his work remained a hallmark of Marxism throughout these sixteen turbulent years and thereafter. The major difference was their far more public manifestation in the form of organisational schisms. Several of the major splits in the Marxist movement in the first three decades of the twentieth century can, in fact, be traced back in part to the on going battle over determinism versus voluntarism in Marxist theory and practice. Revolutionary syndicalism, at any rate with solid roots in the anarchist tradition, can be interpreted as a product of the increasing immobilism of Second International Marxism. The creation of the Third International has likewise many points of origin in the rebellion of party activists against the quasi-religious belief in the inevitable forward march of labor by many leading lights of the Second International. Even Pierson's three faces of Marxism survived and prospered, although the most visible departure in this respect was the addition of a fifth face on top of the party-pragmatic fourth: the defense of the Soviet fatherland as a new variant of 'apologetic' Marxism.

In the years 1928-1933, as in 1887-1912, the model party of the Second International was still beholden to the determinist view. In Donna Harsch's words: "Social Democrats saw themselves as objects of bourgeois society rather than as subjects who could fundamentally shape events." (240) This legacy weighed heavily on German socialists who were then facing an unprecedentedly and unusually dynamic enemy, fascism. The struggle against nazism soon became the litmus test for the Marxist movement, and socialists everywhere turned their attention to German events, as German social democracy was still regarded as the authority within Second International Marxism.

Donna Harsch lays bare another one of the SPD's constitutional contra- 
dictions: the uneasy though symbiotic coexistence of a fair amount of internal dynamism with a distinct tendency towards external immobility. Whereas on a local and district level the party repeatedly manifested unusual instances of creativity and flexibility, precisely this welter of ill-coordinated local initiatives led to reinforced passivity on the national leadership level. For the most part, the party executive continued to adhere to time-worn strategy and tactics, no longer adequate to respond to rapidly changing circumstances. Unfortunately, major portions of Harsch's study focus precisely on the barely evolving leadership response rather than the innovations from below.

Where Harsch is best is in her discussion of two qualitatively new departures for the SPD as a whole, though in one case the proposal was never adopted and in the other only when it was already too late. Her discussion of the first new tactic, various ill-fated attempts to have the party officially adopt a positive economic stimulus plan to combat unemployment, is well-taken and informative. Her best pages, however, are in her chapter on the second initiative, the Iron Front. In December 1931 the SPD, its affiliated trade union bodies, its paramilitary force, and its Sports Federation engaged in the construction of an extraparliamentary umbrella organization specifically designed to combat the radical Right. It constituted a final recognition that defensive actions were increasingly counterproductive and that the best defense would henceforth be an offense.

New methods of struggle and new means of propaganda were designed and implemented as key features of Iron Front politics. Under the inspiration of a Russian émigré, Sergei Chakhotin, new symbols (the three arrows) were designed to unify and galvanize the party's ranks. New emphasis on iconographic and ritualistic elements of propaganda were deployed to instill enthusiasm and purpose. The results surpassed most expectations. From a relatively stayed and immobile organisation the SPD began to turn into an organisation espousing militant republicanism and popular socialism. "Excitement gripped SPD districts of all political orientations." (173) SPD election results were most favorable in those districts or cities where the new tactics of the Iron Front had been applied most rigorously, inspiring a rapid spread of this approach.

Yet right in the middle of the first national election campaign held under the auspices of Iron Front dynamism, the July 1932 electoral contest, the bubble burst. When Chancellor Franz von Papen arbitrarily toppled the last SPD government stronghold, the SPD-controlled Prussian state government, the SPD leadership decided to give in without struggle. For most party activists, recently energized by the creativity of the Iron Front, this passive act of acquiescence by the executive denoted the continuation of SPD politics as 
usual. When push came to shove, the SPD could not overcome its inertia bred over many decades of firm belief in the automatism of social developments.

Neither Harsch's discussion of the search for an active economic policy nor her rendering of the Iron Front campaigns are totally new historiographical contributions, but they are the most concise and eloquent description in the English language. An additional interesting key feature of Harsch's work is her focus on the crucial contributions by party leftists and especially neo-revisionists in the closing years of the Weimar Republic. What motion there was within the SPD often emanated from these circles. Yet, tragically, the Iron Front was one of the few incidents when left oppositionists and neo-revisionists were joining forces to outflank traditionalist party functionaries. Even the more flexible proponents of the Iron Front, however, turned a cold shoulder on defenders of economic planning mechanisms. And, vice versa, advocates of economic planning shied away from radical political action. "In fact, the sympathetic historian becomes exasperated precisely because so many of the pieces of the puzzle were there, yet the puzzle could not be solved." (241) Six months after the Papen coup in Prussia, Germany was led by a legallyappointed dictator.

Donna Harsch does not believe that the Nazi conquest of Germany was inevitable. Weimar Germany labored under the legacy of structural preconditions compounded by conjunctural negative factors, primarily the Great Depression, which made positive solutions hard to come by. But precisely the interaction of structure and contingency engendered the primacy of politics in the closing years of the Weimar Republic. It was up to forces such as the SPD to provide the answers. Weighed down by immobilism, the SPD could not meet the challenge.

The person who came closest to solving the puzzle left unfinished at the end of Harsch's study was a Flemish social democrat, Hendrik de Man, then living in Germany. His closest political associates were precisely the neo-revisionists at the center of German Social Democracy and the Rise of Nazism, with Carlo Mierendorff, the leading defender of Iron Front tactics, a frequent interlocutor. Deeply disturbed by the rise of fascism in Germany, de Man began to draw conclusions which soon crystallized into a concerted economic and political plan, designed to create the dynamism that had failed the German socialist movement confronted by Nazi successes. Composed of elements drawing on the most innovative features of SPD activism - economic planning designs; united front tactics; new departure in propaganda methods; the creation of a positive, offensive image - Hendrik de Man chose the neo-revisionist stronghold of Hamburg as his first home base from which to conquer 
the national SPD and thus change the face of German politics.

It was his misfortune that his project did not get off the ground until two months before the end of Weimar Germany. He was therefore forced to change the terrain of battle to his native Belgium where, within less than a year, he managed to change completely the outlook and direction of Belgian social democracy and to captivate much of the nation. Yet under the pressure of national and international events, by 1935 de Man once again changed his focus and engaged his party in a series of coalition governments, effectively ending the short-lived mystique and promise of the Plan de Man.

It is unfortunate that Donna Harsch passes over de Man's contribution in silence. And this neglect goes hand-in-hand with her somewhat undifferentiated assessment of the role of neo-revisionism in general. Harsch notes within German neo-revisionism a de facto split into a 'national' tendency and a 'left populist' or 'neo-Jacobin' tendency, with most of her attention bestowed on the latter group, amongst them Carlo Mierendorff. Harsch is convinced of their essentially moderate nature and repeatedly assures the reader that their radicalism and use of class language in the campaigns of the Iron Front were a mere "concession to activists and leftists." (183) As an underground activist, Mierendorff later made much use of national, as opposed to class-based, language. And, combined with his moderation prior to 1931, it only stands to reason, implies Harsch, that the radicalism of 1932 was a temporary tactical ploy.

Yet the case of Hendrik de Man, the close acquaintance of Mierendorff and subsequent puzzle solver, proves that the radicalization of means and goals was a measured and well-reasoned response to changing conditions. Neo-revisionists, just like anyone else, were subject to influences from the world at large. And the politics of late Weimar were desperate enough to cause more than minor adjustments in the political arsenal of flexible thinkers. In the words of de Man, published in the Hamburg SPD daily, the Hamburger $E c h o$, at the very end of 1932: "Given the revolutionary situation of today, nothing is more inopportune than that which was called opportune up to now; now the only things that are possible and practical are what appeared, yesterday, as impossible and impractical."

After the fall of Weimar Germany, Spain became the next hotbed of European social struggles. Starting in the latter months of 1933, Spanish democracy was increasingly rent by vicious social and political struggles, culminating in the Spanish Civil War. No other European country in the 1930s experienced such bitter economic and political class struggles as did Spain in the short lifespan of its Second Republic. Stanley Payne's Spain's First Democracy is a 
comprehensive and detailed narrative of the political history of the Second Republic up to the outbreak of civil war. While openly proclaiming his preference for conservative options, he aims to give a factual account, and he has largely succeeded in doing so.

Stanley Payne is only one of many scholars pointing to the radicalization of the Spanish section of the Second International, the PSOE, as a key factor in the disintegration of the Second Spanish Republic. In part as a reaction to the very recent failure of German social democracy in its attempt to stem the tide of the radical Right, Spanish social democrats, starting in the fall of 1933, embarked on an openly revolutionary course of action, complete with secret insurrectionary plans, party militias, stockpiling of weapons, and the like. Reaching a first highpoint in the Asturian Commune of October 1934, significant elements of Spanish social democracy continued to deny support to republican institutions and steadfastly pursued their collision course, helping to polarize further an already highly politicized nation. It was the most remarkable departure from Second International determinism in the history of European social democracy.

Where Payne goes overboard in his assessment of Spanish socialism in the 1930s is in his tendency occasionally to imply that PSOE radicalism was the key factor behind the polarization of Spain. Payne is correct in pointing to social democrats as $a$ key source of plentiful instances of individual terrorism in Second Republic Spain, particularly in the six months prior to the Franco coup. Yet to go as far as to project primary blame for Spain's political paroxysms onto the PSOE is a highly debatable proposition.

Still, what happened in Spain's first democracy so that a social democratic party felt compelled to adopt revolutionary tactics including bouts with individual terrorism? After all, as Payne makes clear, Spanish social democracy, up to 1933, was one of the traditionally most moderate and complacent sections of the Second International. As a matter of fact, it can be argued that anarcho-syndicalism became such a prominent force in Spanish politics in part as a result of traditional PSOE moderation and peaceful coexistence with the status quo in the decades leading up to the proclamation of the Second Republic. This is not the place to lay out the contours of Spanish politics and society in the 1930s, a task admirably completed by Payne's work under review. Let me instead draw attention to the overall explanatory framework employed by Stanley Payne, outlining the structural and conjunctural sources of the problems giving rise to PSOE radicalism and voluntarism and, ultimately, the Franco regime.

In a few isolated but very important pages, Stanley Payne summarizes the German Marxist historian Detlev Peukert's assessment of the origins of 
Weimar Germany's problems with democracy and adapts Peukert's argument to Spanish conditions. In his work on Weimar Germany, Detlev Peukert diagnosed the Weimar Era as constituting the crisis years of classic modernity in Germany. Ever since the turn of the century, but particularly prominently in the fourteen years of the Weimar Republic, German society experienced rapid and massive encounters with modernity: modern social policy; modern economic and technical developments; revolutions in natural science; radical experiments in modern art, music, architecture and literature; and much more. This unprecedentedly rapid modernization of society and culture simultaneously fascinated and horrified contemporaries. As a result, each new departure called forth an equally vigorous countermove, so that Weimar Germany saw a vast number of conflicting tendencies and movements at play in all walks of life and leading in all directions simultaneously. Given the constraints of the concrete political and economic conjuncture after 1928, Weimar democracy was likely to capsize on these rocky shores, and capsize it did.

Where Payne takes off from Peukert is in his recognition of a similar crisis of modernity in the Spanish state, but with the additional birthmark of relative backwardness. Careful not to declare Spain an underdeveloped nation, Payne underscores Spain's experience of "partial and uneven modernisation," (123) its peculiar hybrid status between modernization and underdevelopment. "Modern Spanish politics had regularly featured a rather unique conjunction of advanced political forms and institutions amid socioeconomic backwardness... . The opportunity for mass mobilisation and untrammeled democracy [during the brief lifespan of Spain's Second Republic] amid the depression, following an unprecedented generation of accelerated modernisation, suddenly raised the classic 'Spanish contradiction' to a new level that made revolutionary challenges almost inevitable, though not at all irresistible." (381)

Similar to Donna Harsch, Stanley Payne subscribes to the primacy of politics thesis. Recognizing Spain's predicament as the outgrowth of an unfavorable combination of long-term structure, conjuncture and day-to-day politics, Payne is adamant in placing most blame on Spanish politicians. As a logical consequence of this approach, Payne, like Harsch, pays most careful attention to political affairs and does not hesitate to take sides. But whereas Harsch places most faith in innovative departures within social democracy, Payne shows his conservative colors quite openly in his recommendation that a Center-Right coalition would have been the best solution for the early years of the Republic. And, in his opinion, the closing years up to 1936 would have been best served by either a "national Republican dictatorship" (350) or even a government by the CEDA, the Spanish homologue to the Austrofascist Social Christian Party of Dollfuß and Schuschnigg, advocates of "a semicor- 
porative and more authoritarian system" (380) which would have put an end to democracy but, according to Payne, would also have pre-empted the civil war and the Franco regime.

As can be surmised from these comments, Payne never shows even an ounce of sympathy for the forces of the Spanish Left, Marxist or otherwise. Yet his valuable comments on the relevance of what some Marxists have termed the 'law of uneven and combined development,' in addition to his rigorous objectivity in outlining the highlights of the political life of Spain's Second Republic, make his book a valuable addition to the slowly increasing supply of Spanish historical studies in the English language. Spain's First Democracy is proof of the fertile engagement of leading conservative historians with the contributions of Marxist historiography. It is more than symptomatic that Payne chose two brief sentences by Antonio Gramsci as his frontispiece.

Weimar Germany and Spain's Second Republic constitute two instances dramatizing the relevance of structure, agency and contingency in the shaping of modern European history. The victory of the radical Right and the collapse of republics, argue Harsch and Payne, were not predetermined outcomes of the crisis years of classic modernity, though certainly not unlikely results. Engagement in the political process could and did substantially alter the eventual outcomes. Determinism and voluntarism, as described by Pierson for early German social democracy, each left their own imprint not only on the history of the Left, but on the trajectory of entire nations. In the case of the late Weimar SPD, the legacy of determinism turned out to be as destructive as the subsequent voluntarist experiments by the Second Republic PSOE. It was not for lack of trying that European Marxism failed to meet the challenge.

One month prior to the Franco coup, Spain was racked by a strike wave involving as many as one million workers. This work stoppage was proportionately equal to the simultaneous two-million strong work stoppage in France. The same turbulent month of June 1936 witnessed an even more astounding strike epidemic in Belgium, where a fifth of the entire workforce walked out. In France and Spain these labor struggles marked the summit and supercession of the Popular Fronts. The Belgian strikes turned out to be a similar highpoint of Belgian depression politics. With the outbreak of civil war in Spain on 17 July, the Spanish and European (largely Marxist) working class Left began to lose its recently regained momentum and found itself increasingly on the defensive. By the onset of World War II the European Left was marginalized beyond recognition. Given the subsequent itinerary I sketched in the introduction to this essay, June 1936, then, can arguably be regarded as the endpoint of the classic years of Europe's orthodox Marxist Left. 


\section{0 left history}

What accounts for this fifty-year period (1887-1936) in which Marxism came to the fore not only as an ideology but as a social movement with substantial working-class support? What appears to unify these classic decades of the European Left, when class struggle politics and economics appeared to shape European politics and society more than ever before or since?

This may be the place to draw attention to the Gramsci quotation chosen by Stanley Payne to introduce his book: "The old is dying and the new cannot be born. In the interregnum, a great variety of morbid symptoms appear." Departing from Gramsci's meaning of these phrases, could it be that the classic years of European Marxism, the decades when Marxist predictions came close to be true, were so turbulent not because the European proletariat came into its own but instead because of the relative immaturity of bourgeois civil society? Were the years of 'post-modernity' not the years of 'late capitalism' but the years of mature capitalism? Could it be that the years of 'classic modernity' were the first and final decades of orthodox Marxist purchase on social reality? Could classic Marxism be considered an ideology intimately linked to the crisis decades of classic modernity rather than the steady rise of the proletariat to world-historical importance and hegemony? If this is the case, what then will follow mature, 'post-modern' capitalism? What will be the contours of an emancipatory project in the twenty-first century? Can orthodox Marxism be sufficiently reconstructed to serve as a method and inspiration?

Instead of providing fragmentary indications towards a tentative answer, let me close with yet another citation of Hendrik de Man, whose following statement holds true as much for the closing decade of the twentieth century as it did in 1933: "I believe, to say it in a nutshell, that the socialism of the coming generation will be, on penalty of total failure, as different from the socialism of our fathers as their socialism differed from the Communist Manifesto." 